\title{
The Literature Review about the Research on Learning Style Both Abroad and at Home
}

\author{
Jingguang Li \\ Foreign Language College, Huaiyin Institute of Technology, 223003, Jiangsu, China \\ Email: sunlightli@qq.com
}

\begin{abstract}
Learning style, as one of the learners' factors which have a great influence on the foreign language teaching, has been laid on more emphasis by some linguists, researchers and teachers in the recent years. According to Keefe, it refers to "cognitive, affective and physiological traits that are relatively stable indications of how learners perceive interact with and respond to the learning environment" (Keefe, 1979, p.4). Making some research on learning styles will facilitate the teachers' further realization on the students' learning prevalence and promote the improvement of their teaching constantly to satisfy the students' demand and raise the foreign language teaching level. Starting with the introduction of the definition and categories of learning styles, the thesis mainly elaborates the researches on learning styles abroad and at home, in the hope of providing most teachers with some references for their further study in the future work and pushing forward the improvement of the foreign language teaching level.
\end{abstract}

Index Terms-learning styles, learner-centered, the definition and categories, the foreign language teaching, implication

\section{INTRODUCTION}

In the recent two decades, with the development of the scientific technology and the increase of the international exchange, foreign language teaching has experienced an unprecedented reform, which will surely bring about a series of changes in educational thoughts. Teaching method---a central issue dominating foreign language teaching for about two centuries, is losing its previous appealing power among researchers and language teachers. The emphasis that teachers and researchers are laying on has shifted from "How to teach" to "How to learn", resulting in the prevalence of the "Learner-Centered" in the field of foreign language teaching.

However, the most challenging problem facing all the foreign Language teachers is how to achieve the goal of centering on learners. As a result, more and more researchers and language teachers are paying great attention to some factors related to learners themselves, among which the more salient ones are learning styles --- "cognitive, affective and physiological traits that are relatively stable indications of how learners perceive interact with and respond to the learning environment" (Keefe, 1979, p.4).

\section{The DEFINITION AND THE CATEGORIES OF LEARNING STYLES}

\section{A. Definition}

As a psychological term, style was formally introduced by Allport in 1937 when he identified it to be a means of identifying distinctive personality types or types of behaviors. With the further development of some social sciences such as Psychology, Linguistics, and SLA, more and more affective, cognitive and physiological factors are integrated into its category. Therefore, Brown (1994) refers to it as a consistent and rather enduring tendency or preference within an individual and styles as those general characteristics of intellectual functioning (and personality types as well) that especially pertain to one as an individual that differentiates one from some one else.

With the emergence of cognitive psychology, some cognitive psychologists put forward a more specific term --cognitive style, which refers to an individual way of processing information. It is used for describing or analyzing the researches into problem solving and sensory or perceptual abilities. And this research provides some of the first evidences for the distinctive styles.

In 1970s, as researchers turned to styles in learning and teaching, the concept of learning style emerged, which, unlike cognitive style, focused on educational situation where style was seen as most useful (Riding\& Cheema, 1991. in Sternberg etal, 2002). It was just then that psychologist and linguists began to do some research on learning styles. Keefe, as a prominent figure at the time, defines them to be "cognitive, affective and physiological traits that are relatively stable indications of how learners perceive, interact with and respond to the learning environment" (Keefe, 1979. in Brown 1994. p.105).

But Garger and Guild perceive learning styles as "stable and pervasive characteristics of an individual, expresses through the interaction of one's behavior and personality as one approaches a learning task (Garger \& Guild, 1984, in Reid, 1995, p.9). From the above definition, we can see that pervasiveness and consistency seem to be common features 
of learning styles. Since 1980s and early 1990s, the research about learning styles has become more mature and systematic; some researchers have incorporated their own unique perspectives or new understandings into the definition of the term. Scarcella redefines it as "cognitive and interactive patterns that affect the way in which students perceive, remember and think" (Scarcella, 1995, in Reid, 1995, p.114). And Maine Carob (1986) also provides her definition for learning styles, according to her, learning styles are the ways that the students at any age are affected by their (a) immediate environment, (b) own emotionality, (c) sociological needs, (d) physical characteristics and (e) psychological inclinations when concentrating and trying to master and remember new or difficult information or skills.

The above definitions are summarized by Kinsella: "Learning styles refer to individual, natural, habitual and preferred ways of absorbing, processing and retaining new information and skills which persist regardless of teaching methods and content area" (Kinsella, 1995, in Reid, 1995, p.171).

\section{B. Categories}

Concerning the category of learning styles, it is impossible to set a definite one facing many different classifications. Many researchers have made some investigations on different aspects of learning styles, on basis of which some different terminologies are labeled, frequently obscuring our understanding. Often some terminologies and categories overlap, which makes learning styles' research complicated and challengeable.

Riding and Cheema (1991), after reviewing the descriptions, correlations, methods of assessments and effects on behaviors of more than 30 labels, concluded that they could be grouped into two fundamental dimensions, which they termed holistic-analytic and verbal-imagery. This view was confirmed in a further research by Reynar and Riding: "the holistic - analytical style dimension is the one where an individual tends to organize information in whole or parts, and the verbal-imagery style dimension is the one in which an individual tends to represent information during thinking verbally or using mental pictures" (Riding, 2001, p.48).

However, Reid (1995) classifies learning styles into three categories: Sensory Learning Styles, Cognitive Learning Styles and Affective / Temperament Learning Styles. For Sensory Learning Styles, two subcategories are included --Perceptual Learning Styles and Environmental Learning Styles. Perceptual Leaning Styles consist of four different types --- Auditory, Visual, Tactile, Kinesthetic; while Environmental Learning Styles include two different types ---Physical and Sociological. Cognitive Styles are mainly made up of four different sets --- Field-independent / Field--dependent, Analytical /Global, Reflective / Impulsive and Kolb Experiential Learning Model. And in the domain of affective or temperament, the following three subcategories are contained --- Myers-Briggs Temperament Styles, Tolerance of Ambiguity Styles and Right-Briggs Temperament Styles.

Because of the limitation of the paper length, it is not possible to elucidate one by one in detail. Therefore it is appropriate to illuminate the learning styles that are involved in the research. As we have mentioned above, Auditory, Visual, Tactile and Kinesthetic are subsumed into Perceptual Learning Styles --- a subcategory of Sensory Learning Styles. For visual and auditory Styles, Brown (1994) makes the following descriptions, "Visual learners tend to prefer reading and studying charts, drawing and other graphic information while an auditory style is characterized by a preference for listening to lectures and audiotapes, of course, most successful learners utilize both visual and auditory input, but slight preference one way or the other may distinguish one learner from another, shaping an important factor for classroom instruction" (p.113). Compared to Brown's description, Oxford's (1995) accounts are more accurate and specific. From his point of view, visual students prefer to learn via the visual channel, and therefore, they like to read something that requires concentration and time spent alone. Visual students need the visual stimulation of bulletin boards, videos and movies; they must write direction if they are to function well in the classroom. However, auditory students enjoy the oral-aural learning channel, thus they want to engage in discussions, conversations and group work. These students typically require only oral direction. Tactile and kinesthetic preferences are often grouped together into a category called "hands-on or hap tic style". Tactile students need to touch and handle objects; they are happy to make collages, three-dimensional models, shadow-boxes and other artwork that can be related to language learning. Whereas kinesthetic students require movement and frequent breaks in an activity, these are the students who can not sit for longer than 20 minutes at a time, and who like Total Physical Response activities--- games, role plays, that let them get out of their chairs and move around. Group and Individual also belong to the domain of Sensory Styles. Group students often obtain their energy and focus on the events and the persons outside themselves. They share many different interests and lots of friends; they tend to work or learn in groups. In contrast, individual learners usually pay great attention to their inner world, and they are often stimulated by their own ideas and feelings. They prefer to work alone or in a pair with someone they know well; they dislike lots of continuous group work in English classroom.

In the cognitive domain, some researchers make a distinction between Field-dependent and Field-independent, Analytical and Global, Reflective and Impulsive. Field-independent and Field-dependent are the most widely discussed learning styles; quite a few scholars regard FI / FD as an important section in their writings, and give a detail elaboration. According to Oxford (1990), Field-independent refers to the ability to separate easily the key detail from an ambiguous context through the use of analysis. Research with people at all ages suggests that field-independent people are less sensitive to the social context, are more detached and more logical than field-dependent people and they prefer more structured, analytical forms of learning. Field-dependent people conversely tend to be more sensitive to the social context; they are perceived as more outgoing and more considerate than their independents peers and they perform well with less structure in their learning. As for the differences between Reflective Styles and Impulsive Styles, reflection is 
defined a tendency to stop and consider options before responding, often resulting in great accuracy while impulsivity is the tendency to respond immediately more fluently and often inaccurately. Concerning Global Styles and Analytical Styles, Global Styles refer to tendencies to process the information and understand the input from a totality, and achieve an overall interpretation of them by analyzing each part respectively. Analytical Styles refer to tendencies to process the information from the details and obtain a complete understanding by integrating the separate parts into a whole. It seems that global learners process information simultaneously and look for patterns. However, when analytical learners processes the information, they pay great attention to the details instead of the connection between different parts.

The differences on the tolerant degree of ambiguity between different learners belong to the affective / temperament category, we can see the following descriptions on the persons with tolerance of ambiguity in Brown's writings (1994). The person who is tolerant of ambiguity is free to entertain a number of innovative and creative possibilities and uncertainties. Norton (1975, in Reid, 1995) conceives of intolerance of ambiguity as "a tendency to perceive or interpret information marked by vague, incomplete, fragmented, multiple probable, unclear meanings as actual or potential sources of psychological discomfort or threat" (p.88).

Of course, there are some other classifications for the category of learning styles. As well as the category provided by Reid, Richard and Stephen also put forward a pattern for classifying learning styles. According to them, learning styles can be divided into four categories - Based on learning process; Based on learning orientation; Based on learning preference; Based on the development of cognitive skill. Each category includes many different types of learning styles (Riding \& Rayner, 1998). Oxford (1992) also suggests that learning styles have four main aspects, all relating to each other --- cognitive, affective, physiology, and behavioral, here, there is no enough space to illustrate one by one, concerning the limitation of the paper length.

\section{RESEARCHES OF LEARNING STYLES ABROAD}

\section{A. Researches of Learning Styles' Influence on Language Development}

In 1993, Carrel and Monroe did a research associated with the relationship between learners' learning styles and language development. By using the Myers-Briggs Type indicator with three groups of students, they found some relationship between MBTI and holistic rating.

Some researches have something to with the influence of learning styles on language achievement and proficiency. In 1986, Chappell and Robert measured tolerance of ambiguity in learners of English as a second language in Illinois, and they found that learners with a high tolerance for ambiguity were slightly more successful in certain language tasks, And the potential impact of learning styles on language achievements was also verified in the later research carried out by Oxford (1992).

Perhaps, the learning styles examined widely for this purpose are Field-independent and Field-dependent. In a study with English-speaking learners who are learning French in Toronto, Naimen (1978) finds that field independence correlates positively and significantly with language success in the classroom. Abraham (1985) finds that second language learners who are field independent perform better in deductive lessons while those with field-dependent styles are more successful in making some inductive lesson designs. Other more recent studies provide further evidences of a field independent style for second language success.

Most researchers try to turn out a close relationship between learning styles and language development, yet there are some still some different opinions existing. Therefore, it's quite early for us to conclude that one pole of the style dichotomies is better than the other.

\section{B. Researches on Factors Affecting Learning Styles}

In one of his writings, Nelson (1995, in Reid, 1995) from Georgia State University makes a careful investigation on the learning styles of Chinese learners and Japanese learners to find out the influence of cultural factors on learning preferences. As we have seen, both Japan and China are greatly influenced by Confusion philosophic principles, and the Confusion tradition is highly valued on education, particularly in educating the members of society as to how human should relate and interact with each other. Through Condon's (1984) findings, he contends that one of the important characteristics of Japanese learners is reflectivity. They did not impulsively or immediately begin their work; instead, they waited until all of the papers were distributed. The second aspect of Japanese's learning styles, for Nelson, is the sensitivity to the total environment in which learning is taking place, and a third component of a Japanese style is modeling, which means learning by watching someone model a new skill. In term of Chinese learners' learning predilections, one of the most important features is cooperation between different learners, this preference for cooperation contrasts with the U.S preference for individualism and competition. From the analysis and comparison, a close relationship between culture and learning styles can be shown clearly.

Some other researches have something to do with gender. By summarizing and analyzing lots of studies, Oxford (1995) concludes that the tactile and kinesthetic learning styles might relate to the spatial ability prominent in the masculine gender, because males do seem to have an edge in some spatial learning tasks. It is also possible to predict that nontraditional females will show these preferences more frequently than traditional females. Concerning auditory learning styles, the auditory ability in a foreign language may be greater in females than in males which can be shown in the study by Eisenstein (1982). 
In the cognitive domain, based on lots of researches, Oxford also has come to the following conclusion. For adolescents and adults, sometimes even children, males are usually more field-independent and females are more field - dependent (Good \& Brophy, 1986; Shipman \& Shipman, 1995, in Oxford, 1995). Field-independent learners often males have advantages in language achievement. But this might relate to the analytic nature of most written language achievement tests and many grammar-based (analytic) language-learning activities. Analytical, field-independent learners ordinary select logic-based learning strategies such as deductive reasoning (Oxford \& Levine, 1992). Field-sensitive individuals often females with their more interpersonal and global orientation, might do better in less analytical aspects of overall communicative competence, such as sociolinguistic competence. Global, field - dependent learners choose non- analytical strategies that involve searching for the main idea and intuitively guessing from multiple to contextual clues - frequently social ones -when some pieces of information are missing (Oxford\& Levine, 1992).

Also, Belenky and his colleagues (1986) conduct interviews with college men and women. The researchers assume that in general the two genders have different ways of knowing, men more often through "objectivity and thinking" (abstract analysis), women more often through "subjectivity and feeling" (personality experience).

These researches show that males and females in general, employ different routes in language learning. More males than females might take the thinking approach focusing on rules, facts and logic, avoiding the more personal interactions, whereas more females than males might like the feeling approach in which there is a great deal of interaction, a high degree of empathy and cooperative learning.

\section{Researches on Other Issues Related to Learning Styles}

Rossi-le (1995) studies the perceptual learning styles of 147 adult immigrants in ESL programs from two community colleges, using Perceptual Learning Style Preference Questionnaire and the Strategy Inventory for language learning. The goal of the study is to investigate the role that perceptual learning preferences have in determining language-learning behaviors and to examine the relationship between the learners' preferred perceptual leaning styles and the strategies approaches to language learning that they choose. Consequently, Rossi-le finds that the majority of adult immigrant students display a major learning style preference for the tactile kinesthetic modes; these learning styles contain a practical experiential approach to learning, In addition, all language groups indicate a preference for group learning but they suggest only a minor or negative preference for individual learning.

By collecting the responses from 62 Chinese ITA (International Teaching Assistants), with the Keirsey Temperament Sorter and the Myers-Briggs Temperament Inventory, Torkelson from Kyrgyz State University has done a research on the learning styles of Chinese ITAs.

After comparing the results of the survey with the learning preferences for the general American undergraduates, he notices that the 62 Chinese ITAs are significantly less extroverted and more introverted than the general U.S undergraduates, while three quarters of the U.S undergraduates characterize themselves as extroverts, more than half the ITAs report that they are introvert. Next, one-quarter of undergraduates report having thinking /judging orientations, however more than 40 percent of ITAs describe themselves in that way; in addition, nearly 40 percent of the U.S undergraduates describe themselves as sensing / perceiving orientations while only 4 percent of the ITAs classify themselves into this category.

The results from the KTS also indicate that a great majority of the U.S undergraduates preferred to learn by interacting with others, doing hands-on activities and being stimulated. However most of the Chinese ITAs consider the teaching process to be completely planned, impersonal, instructive and analytical; they conceive the learning process of solitary conceptual work.

Such a result obviously suggests a mismatch between Chinese ITAs and U.S undergraduates in learning styles, which is certain to lead to an unfavorable impact on classroom teaching.

\section{RESEARCHES OF LEARNING STYLES IN CHINA}

The study on learning styles in China started much later than that abroad, and it was not until 1990s that some scholars began their researches on learning preferences.

In 1992, Wang Chuming examined 490 English major students, using Reid's Learning Style Preference Questionnaire with a little modification. By comparing the results with Reid's and Melton's, Wang found that most of the students participating in the surrey prefer tactile styles and only a few of them favored group work.

$\mathrm{Hu}$ Xiaoqiong (1997) also has discovered the same result. Through her observation with 236 English major participants, she has found that most students dislike the learning style of group work. Moreover, they have been found to favor multidimensional styles instead of one only.

With Keefe and Monk's learning style test and CET band-4 as the instruments, Yu Xinle (1997) tests 149 students from three universities in Beijing. He has found that gender does not play any role in shaping learning styles, and there is a significant correlation between sequential processing information, memory styles and the learners' English achievement among 24 observed styles, but any considerable correlation has not been found with other 22 styles.

In 2001, Cheng Zhihong, studying for a doctor degree in the university of South Patoka America, tested teachers and some fourth--grade students at Zhonghua Institute of Medical Technology in Taiwan. The purpose of the study was just to compare the preferred learning styles of the students in the seven programs at the institute. As well, according to the 
gender, the research examined the preferred learning styles of the students and identified the differences on their preferred teaching and learning styles between the teachers and the students.

Using Reid's Perceptual Learning Style's Preferences Questionnaire as the instruments, after receiving the survey papers from 68 teachers and 666 students in the seven different departments, he came to the following conclusion finally. (a) Students looked on auditory style as their most favorable learning styles and regarded individual styles as their least preferred styles. (b) Both teachers and students liked the individual teaching and learning styles. (c) Most teachers expected their students to do with their learning with the kinesthetic and group styles to a greater degree than students wanted to use them. As well, Liyan (2002)from Wuhan Science Technology University made some investigation on Chinese adults learning styles, analysing factors shaping their different learning preferences. Li Guangchao (2000) from Huanan Normal University also did some research on the relationship between learning styles and English teaching strategies, putting forward four different types of English teaching strategies.

So far, in China, the learning style of English learners in the secondary school hasn't become a prevalent issue especially among most researchers and high school teachers, and only a little has been done on the relevant researches, which can be shown from the studies listed above. Therefore it's not surprising why we put forward the issue and make a further investigation.

\section{CONCLUding WordS}

Learning style, as an issue that has been paid great attention in the recent years by some linguists and scholars, is still a new topic to most of us. Therefore, it will take a long time for us to find out its real implication on the learner' second language acquisition and play its full part in the foreign language. Undoubtedly, it requires the common efforts from most theorists, researchers and teachers. Only by doing this, can we learn about the learning style of the whole learners clearly and make our daily teaching in accordance with the students' requirements; can we center around the learners indeed in our daily teaching and push forward the development of the whole foreign language teaching.

\section{REFERENCES}

[1] Abraham, R. (1985). Field Independence-dependence and the Teaching of Grammar. TESOL Quarterly 20:689-702.

[2] Allport, G. W. (1937). Personality, a Psychological Interpretation. New York: Holt.

[3] Belenky, M. F, \& Clinchy, B. M., \& Goldberge, N.R., \& Tarule, J. M. (1986). Women's Ways lf knowing: the Development If self, Voice, and Mind. New York: Basic Books.

[4] Brown, H.D.(1994). Principle of Language Learning and Teaching. Pearson Education Limited. Beijing: Foreign Language Teaching and Research. 2001.

[5] Condon, J.C.(1984). With Respect to the Japanese. Yarmouth, Me: Intercultural Press Inc.

[6] Chappell, C. \& P. Green. (1992). Field Independence in Second Language Acquisition Research. Language Learning 42.47-83.

[7] Chi-Hung Cheng. (2001). Preferred Learning and Teaching Styles at a Selected Junior College in Taiwan. Newyork: Bell Howell \& Information and Loaning Company.

[8] Eisenstein, M. (1982). A Study of Social Variation in Adult Second Language Acquisition. Language Learning, 32(4), $367-391$.

[9] Garger, S. \& Guild, P. (1984). Learning styles: The Crucial Differences. Curriculum Review, 23, 9-12.

[10] Good, T. L. \& Brophy, J.L. \& Brophy, J. E. (1986). Student-teacher Cognitive Styles and Foreign Language Achievement: A Preliminary Study. Modern Language Journal, 66, 263-273.

[11] Hu Xiaoqiong. (1997). The Survey on the Leaning Style of the Chinese Teacher-training College Students. Foreign Language World, (2): 34-37.

[12] Keefe, J. W. (1979). Learning Styles: An Overview. In J. W. Keefe (ed.), Student Learning Styles: Diagnosing and prescribing Programs (p.1-17). Reston, VA: National Association of Secondary School Principals.

[13] Kinsella, K. (1995). Understanding and Empowering Diverse Learners in ESL Classroom. In Reid (ed.), Learning Styles in the ESL/EFL Classroom (p.170-194).USA: Brooks/Cole/Thomson Learning Asia. Beijing: Foreign Language Teaching and Research. 2002.

[14] Li Guangchao. (2005). Learning Style and English Teaching Strategy. Journal of Guangdong Education Institute,(5): $102-105$.

[15] Li Yan. (2002). The Primary Investigation of the Chinese Adults' English Learning Style and its Cause of Formation. Journal of the continuing Education Institute, (2):49-50.

[16] Naiman, S. \& M. Frohlich, H. Stern, and A. Todesco. (1978). The Good Language Learner. Toronto: Ontario Institute for Studies in Education.

[17] Nelson, G.L. (1995). Cultural Difference in Learning Styles. In Reid (ed.), Learning Styles in the ESLEFL Classroom (p.3-18). USA: Brooks/COLE/Thomson Learning Asia. Beijing: Foreign Language Teaching and Research. 2002.

[18] Norton, R. W. (1975). Measurement of Ambiguity Tolerance. Journal of Personality Assessment, 39, 607-619.Toronto: The Ontario Institute for Studies in Education.

[19] Oxford, R.L. \& Levine, R.Z. (1992). Teacher-student Style Wars in the Language Classroom: Research Insights and Suggestions. Bulletin of the Association of Departments of Foreign Language, 23(2), 38-45.

[20] Oxford, R.L. (1995). Gender Differences in Language Learning Styles: What do they mean? In Reid (ed.), Learning Styles in the ESL/EFL Classroom (p.34-45). USA: Brooks/COLE/Thomson Learning Asia. Beijing: Foreign Language Teaching and Research. 2002.

[21] Reid, J. M. (1995). Learning Styles in the ESL/EFL Classroom. USA: Brooks/Cole/Thomson Learning. Beijing: Foreign Language Teaching and Research. 2002.

[22] Riding, R.J., \& Cheema, I. (1991). Cognitive Styles: An Overview and Integration. Educational Psychology, 11, $193-215$. 
[23] Riding, R.J., \& Rayners, S.(1998). Cognitive Styles and Learning Strategies. London: David Fulton.

[24] Riding, R. J. (2001). The Nature and Effects of Cognitive Styles. In Sternberg (ed.) Perspectives on Thinking, Learning, and Cognitive Styles. London: Lawrence Erlbaum Associates.

[25] Rossi-le, Laura, (1995). Learning Styles and Strategies in Adult Immigrant ESL Students. In Reid (ed.) Learning Styles in the ESL/EFL Classroom (p.118-125). USA: Brooks/Cole/Thomson Learning. Beijing: Foreign Language Teaching and Research. 2002.

[26] Scarcella, R. (1990). Teaching Language Minority Students in the Multicultural Classroom. Englewood Cliffs, NJ: Prentice Hall/Regent.

[27] Shipman, S. \& Shipman, V.C. (1995). Cognitive styles: some conceptual, methodological and applied issues. In E. Gordon (ed.), Review of Research in Education. (p. 229-291). Washington, DC: American Educational Research Association.

[28] Stenberg, R.J. \& Li-Fang, Zhang. (2002). Perspectives on Thinking, Learning and Cognitive Styles. London: Lawrence Erlbaum Associates.

[29] Wang Chuming. (1992). The Survey on the English Learning Style of Chinese Students: The Chinese Students' English Learning Psychology. Gui Shichun (edt.). Hunan Education Publishing House, 72-89

[30] Yu Xinle. (1997). The Research on the Learning Style of the Chinese Undergraduate Students. Foreign Language Teaching and Research, (1): 59-65.

Jingguang Li was born in Xinxiang, Henan Province on October 14, 1966. He received his Master Degree in English Curriculum and Teaching Methodology from Henan Normal University, China in July, 2005. Since then he has worked as a college English teacher in Foreign Language College, Huaiyin Institute of Technology, Jiangsu Province, China. As an English teacher having worked for more than twenty-fives years, he has accumulated lots of teaching experiences in the daily teaching practice. Because of being good at putting the latest teaching theory into the classroom teaching practice, he has been praised by the college leaders, the colleagues and the students. In addition, as a vice professor and a post graduate whose research interests involve English Teaching Theory and Practice, he spent most of his spare time in doing some researches on college English Teaching. So far, he has published more than ten articles in some relevant teaching magazines or journals. 